The International Journal Of Engineering And Science (IJES)

|| Volume || 6 || Issue || 1 || Pages || PP 34- 38|| 2017 ||

ISSN (e): $2319-1813$ ISSN (p): $2319-1805$

THE IJES

\title{
Replacement of Fish Meal with Fish Head Meal in the Diet on the Growth and Feed Efficiency of Spiny Lobster, Panulirus Ornatus Under Reared in Sea Net Cage
}

\author{
Agus Kurnia, Yusnaini, Wellem H.Muskita, Oce Astuti, Muhaimin Hamzah, \\ Department of Aquaculture, Faculty of Fisheries and Marine Science, Halu Oleo University, Kampus Bumi \\ Tridharma, Anduonohu Kendari Southeast Sulawesi, Indonesia
}

\begin{abstract}
-
The availability of fish head meal (FHM) as a substitute for fish meal (FM) was evaluated in lobster (initial weight: \pm 0.02 ) diets containing three levels of FHM (from 0, 25\% and 50\%). After 90 days, weight gain averages were g for fish fed diet in which FM was partially substituted with 100, 75, and $50 \%$ FHM, and feed conversion ratios were $3.20,3.05,4.01,3.65$ and 4.46, respectively. No differences were obtained in weight gain, FCR, FE and SR for all treatments. The lobster fed diet C (50\% FM : 50\% FHM) was highest in FE and followed by the shrimp fed diet B (75\% FM),diet A (100\% FM), respectively. SR was highest in the lobster fed diet $C$ and the lowest was found in the lobster fed diet A. This study concluded that FHM could replace FM up to $50 \%$ in the diet without compromising growth and survival rate of rock lobster juvenile.
\end{abstract}

Keywords: Fish meal; Fish head meal; Substitute fish meal; net sea cage, spiny lobster

Date of Submission: 31 December $2016 \longrightarrow$ Date of Accepted: 30 January 2017

\section{INTRODUCTION}

Most of the problem in intensive culture is feed management because it can require around $40-60 \%$ of total production cost of fish culture. The big percentage of feed ingredients is fish meal around $30-60 \%$ of formulated diet ingredients. Fish meal is one of the primary proteins used in fish feeds, because of its known nutritional and palatability characteristics. Beside that fish meal is known also as an expensive ingredient. Fish meal (FM) is considered the most desirable animal protein ingredient in aquaculture diets because of its high protein content, balanced amino acid profiles, high digestibility and palatability, and as a source of essential n 3 polyenoic fatty acids. However, FM is one of the most expensive macro-ingredients (used in high percentages) in an aquaculture diet. Likewise, with the static or declining fish populations that are used to produce FM, the view held by some is that the use of FM in aquaculture diets is wasteful and unethical. The high cost of FM and concerns regarding its future availability have made it imperative for the aquaculture industry to reduce or eliminate FM from fish and crustacean diets.

The demand for fish feeds is rising by some 5\% a year because production from aquaculture is rising. Nevertheless, the supply of this ingredient cannot increase and prices have increased to a historic high level. In order to sustain aqua feed industry, a great part of nutritional research has been focused on the search for alternative proteins to replace fish meal with more economical protein sources. One of the most potential as an alternatives protein sources is fish head meal.

As a by product of fish processing, fish head has still contain protein, lipid and ash and it is potentially to use it as a source of alternative protein to replace fish meal in the diet of spiny lobster. Utilization of FHM has been applied in the diet of tilapia (Chimanat et al, 2009) and they successful to replace the FM with FHM in the diet of juvenile tilapia till $75 \%$ of replacing. Other studies also had been conducted to the other of protein resources to replace fish meal such as shrimp head meal in litopenaeus schimitti diet (Barbarito et al., 2009), shrimp head meal in the diet of juvenile tilapia.

Studies and information of utilization of $\mathrm{CO}$ in the diet of lobster are still limited. Therefore, the present study was conducted to assess the effect of using FO ingredients based on percentage of replacement with FO practical feeds on the growth and survival rate of lobster juvenile .

\section{Feed formulation and preparation}

\section{MATERIALS AND METHODS}

Ingredients of $\mathrm{CO}$ and $\mathrm{FO}$ were obtained from some traditional fish markets in Kendari, Southeast Sulawesi Indonesia. Some telescopium mussel were collected from seaside around Moramo, in the eastern of Kendari City . Other feed ingredients such as sago meal, corn meal, brain rice meal, fish oil, and top mix (combination 
vitamins and minerals mix) were obtained from a shop farm company. The proximate composition of the FM and FHM are presented in Table 1.

The three experimental feeds were formulated to contain decreasing amounts of FM and increasing amounts of FHM. The ingredient compositions of the diets are presented in Table 2. Diet A was formulated to be similar to a commercial high-quality lobster diet containing $0 \mathrm{~g} \mathrm{~kg}^{-1}$ FHM and $300 \mathrm{~g} \mathrm{~kg}^{-1}$ sarden FM (100\% FM); diet B contained $75 \mathrm{~g} \mathrm{~kg}^{-1}$ FHM and $225 \mathrm{~g} \mathrm{~kg}^{-1}(25 \%$ FHM: $75 \% \mathrm{FM})$ and diet C contained $150 \mathrm{~g} \cdot \mathrm{kg}^{-1} \mathrm{TM}$ and $150 \mathrm{~g} . \mathrm{kg}$ ${ }^{-1}$ FM (50\% FHM: 50\% FM). Three dry feeds were formulated to contain of $40 \%$ protein (isonitrogenous) where before formulated the diet, three of feed ingredients (fish meal, fish head meal and sago meal were analyzed to get the proximate values of the ingredients. Sixth feed was fish catch by product were bought from fisherman and this fish served as a comparison to the formulated feeds. Because of the deference in proximate com- position of the dietary ingredients from tabular values (NRC 1993), diets varied somewhat in actual chemical analysis from calculated values. The formulation and chemical composition of the test feeds are presented in Table 2. The dry ingredients were ground with a hammer grinder, passed through a $0.5 \mathrm{~mm}$ sieve, and mixed in a 30-1 kitchen mixer. Slow sinking pellets were made using a laboratory-scale. The pellets (diameter $4 \mathrm{~mm}$ and length $8 \mathrm{~mm}$ ) were cooled and dried at room temperature.

\section{Diet analysis}

Diets were analyzed to determine percentage moisture, protein, lipid, fibre and ash. Moisture was determined by placement of a 2 -g sample into a convection oven $\left(135^{\circ} \mathrm{C}\right)$ for $2 \mathrm{~h}$ until constant weight was achieved (AOAC 1995; procedure 930.15); protein was determined by the Kjedahl method (AOAC 1995; procedure 990.03); lipid was determined by soxhlet method (AOAC 1995; procedure 954.02); fibre was determined by using the fittedglass crucible method (AOAC procedure 962.09) and ash was determined by placing a 2 -g sample in a muffle furnace $\left(600^{\circ} \mathrm{C}\right)$ for $6 \mathrm{~h}(\mathrm{AOAC} 1995$; procedure 942.05$)$.

Table 1. Proximate composition of the FM and FHM

\begin{tabular}{|l|l|}
\hline Ingredients & Results of crude protein analysis (\%) \\
\hline Fish meal & 69.6 \\
Fish head meal & 54.1 \\
Corn gluten meal & 5.88 \\
\hline
\end{tabular}

Tabel 1. Ingredients and formulation diet of lobster

\begin{tabular}{|l|lll|}
\hline Ingredients & \multicolumn{3}{l|}{ Diet $(\mathrm{g} / 100 \mathrm{~g})$} \\
\hline Fish meal & $\mathrm{A}$ & $\mathrm{B}$ & $\mathrm{C}$ \\
\hline Fish head meal & 30 & 22,5 & 15 \\
\hline Soybean meal & 0 & 7.5 & 15 \\
\hline Corn gulten meal & 25 & 25 & 25 \\
\hline Brain meal & 9 & 9 & 9 \\
\hline Sago meal & 12 & 12 & 12 \\
\hline Wheat flour & 3 & 3 & 3 \\
\hline Fish oil & 10 & 10 & 10 \\
\hline Squid oil & 1 & 1 & 1 \\
\hline Corn oil & 1 & 1 & 1 \\
\hline Top Mix & 4 & 4 & 4 \\
Total & 5 & 5 & 5 \\
\hline
\end{tabular}

Table 2. Formulation and chemical composition of the test feeds.

Table 2. Results of proximate analysis of experimental diets of lobster

\begin{tabular}{|l|l|l|l|}
\hline \multirow{2}{*}{ Parameter (\%) } & Diet & \multicolumn{3}{|l|}{} \\
\cline { 2 - 4 } & A & B & C \\
\hline Protein & 38,28 & 37,69 & 37,32 \\
\hline Moisture & 11,15 & 10,97 & 10,37 \\
\hline Lipid & 2,46 & 2,65 & 2,85 \\
\hline Fiber & 5,45 & 5,14 & 5,43 \\
\hline Ash & 8,02 & 9,93 & 10,79 \\
\hline
\end{tabular}

\section{Juvenile, husbandry and feeding}

An 6-week feeding trial was carried out in net sea cage belong to Cinta Laut Farm Kendari, Southeast Sulawesi, Indonesia. Rock lobster juvenile were obtained from Moramo seaside that catched by using lobster trap. Two weeks prior to the trial, 180 lobster juvenile (initial weight : $0.3 \pm 1.0 \mathrm{~g}$ ) were distributed and reared in 18 boxes $(60 \times 30 \times 45 \mathrm{~cm})$ at 10 lobter per cage for acclimatization. During the acclimatization the fish were fed the formulated diet twice daily. The start of the trial, the acclimated fish were deprived of feed for $24 \mathrm{~h}$, pooled, and 
groups each of 10 the lobster larva were weighed, and randomly stocked into 18 experimental cage, with 3 replication of each treatment.

During the trial, the lobster were hand fed in three times at 08.00, 17.00, and $22.00 \mathrm{~h}$ daily. Dead lobster were replaced throughout the experiment with tagged shrimp from the reserve tanks to avoid density dependent effects but no measurements were made on replacement lobster. Lobster in reserve cages were fed corresponding experimental diets prior to being introduced into experimental tanks. During the experiment, each lobster in one tank was assumed to consume an equal amount of offered feed. Excess feed remaining on the bottom of the tanks was siphoned out $4 \mathrm{~h}$ after feeding, collected, pooled, and dried for the determination of the amount of feed consumed. The percentage of dry matter retained for each diet immersed in seawater for $4 \mathrm{~h}$ was used as a correction factor for calculation of the total estimated feed intake. Sampling was conducted once in 14 days to measure the weight gain of lobster juvenile. The quality of diets was evaluated in terms of daily growth rate $\mathrm{mg}^{- \text {day }^{-1}}$ lobster, feed efficiency (g/lobster), feed conversion ratio (FCR) and percent survival (\%) ( Cho et al., 1985).

\section{Statistical analysis}

All Data were analyzed by analysis of variance (ANOVA) using the SASSAS General Linear Models (GLM) procedure (SASSAS software version 8.2; SAS 1999) to determine whether growth was significantly different among treatment means. Significantly differences between means were separated by Duncan's multiple range test. All percentage and ratio data were transformed to arc sin values prior to analysis (Zar 1984). All statistical computations were performed at the P 1/4 0.05 probability level. Data are presented as untransformed values. Multiple regressions were with growth and production parameters (such as weight gain percentage, SGR, FCR, survival rate as dependent variables, and (1) diet type or (2) fish head mealcontent in diets as independent variables.

\section{RESULTS}

\section{Water quality}

Average monthly morning water temperature ranged from $28.2{ }^{\circ} \mathrm{C}$ in to $29.6{ }^{\circ} \mathrm{C}$. Dissolved oxygen levels averaged $6.8-7.3 \mathrm{mg} . \mathrm{L}^{-1}$. and $\mathrm{pH}$ averaged $8.6 \pm 0.3$ for the duration of the study, and these averages were within acceptable values for growth of lobster (Boyd 1979).

\section{Growth and production}

At the conclusion of the feeding trial, there were no significant $(\mathrm{P}>0.05)$ differences in mean final weight, percentage weight gain, SGR and FCR among treatments. Absolutely growth was obtained in average ranged between $0.25 \mathrm{~g}$ to $0.38 \mathrm{~g}$. The highest of absolutely growth was observed in the lobster fed diet E (100\% TM) and the lowest one was observed in lobster fed diet B (75\% FM : 25\% TM) (Fig.1). While, the FCR was found in average ranged between 1.71 to 2.65. The lowest of FCR was found in the lobster fed diet E and the highest one was found in the lobster fed diet B (fig. 2). In the figure 3 showed that the highest of survival rate was observed in the lobster fed diet A $(63.5 \%)$ and followed by the lobster fed diet B $(58.3 \%)$, lobster fed diet F $(56.9 \%)$, the lobster fed diet $\mathrm{C}(55.0 \%)$, the lobster fed diet D $(46.9 \%)$ and the lowest one was the lobster fed diet $\mathrm{E}(46.4 \%)$, respectively.

\section{DISCUSSION}

The main finding of these studies was that the species of telescopium used in artificial diets and the nature of the dietary fish head meal ingredients affected utilization of diets by, spiny lobster, Panulirus ornatus. Totally replacement of fish meal with fish head meal diet gave better performance compared to all other diets except for survival rate of lobster. The absence of significant differences in daily growth rate feed intake, FCR, survival, between lobster fed all treatment diet present study indicates that the nutritive value of fish head meal meal derived from dehulled skipjack tuna species is comparable to that of fish meal for the juvenile $P$. ornatus. Thus, there is a possibility of using fish head meal as an alternative protein source for fish meal in artificial feeds for P. ornatus at above $45 \%$ inclusion level as a replacement of $30 \%$ of fish head meal on an equal protein basis.

When data from this research are used to calculate specific growth rate measures in $\mathrm{mg} / \mathrm{day}$, comparisons can be made between the results obtained in this study and those previously reported in another lobster species. Using this experimental diet, the best of specific growth rate of $P$. ornatus was obtained an average $7.8 \mathrm{mgr} / \mathrm{day}$ on the best performing diets diet $\mathrm{E}$ in the present study was comparable to that reported for similar sized lobster fed artificial diets in laboratory tanks. Results in this study was higher than Results obtained from the research conducted from Harter et al (2011) suggested that the shrimp fed diet fish meal only obtained SGR in 3.18 $\mathrm{mg} /$ day.

Some animal protein sources such as poultry by-product meal (PBM) and meat MBM as protein alternates are suitable protein ingredients in properly formulated diets for white shrimp (Davis \& Arnold 2000; Forster et al. 
2003; Cruz-Suarez et al.2007) and red claw crayfish (Saoud et al. 2008). However, very high or the complete replacement of FM with these protein ingredients in practical diets for crustaceans, in particular with white shrimp, has been less successful under laboratory conditions (Forster et al. 2003; Hernandez et al. 2004, 2008; Cruz-Suarez et al. 2007). Some research results have shown that FM can be completely replaced by terrestrial rendered by-products and plant protein sources alone or by a blend without adverse effects on growth and survival.

A combination of scallop waste and shrimp head meal (Sudaryono et al. 1995), co-extruded soybean poultry byproduct meal with egg supplement (Samocha et al. 2004), SBM with brewer's grains (Muzinic et al. 2004), a combination of plant protein ingredients (Thompson et al. 2005) or SBM alone (Amaya et al. 2007b) without FM addition in practical diets can be effectively fed to various shrimp species. Guo et al. (2007) stated that combination of various rendered animal ingredients may be more adequate in nutritional value for cuneate drum than the use of the ingredients alone. To make up for a single ingredient deficiency in nutrients, and to improve the nutritional values of alternate protein sources, complementary protein sources to replace FM in practical diets was adopted through a combination of three rendered animal by-products and a plant protein ingredient using a specific formulating proportion for the present study. The dietary inclusion of a mixture significantly affected the growth response of white shrimp at each dietary protein level. There was a trend of reduced growth with increasing the mixture in diets, and significant growth retardation of the white shrimp was observed at the higher level of FM replacement $(714 \mathrm{~g} \mathrm{~kg}) 1 \mathrm{FM}$ for $330 \mathrm{~g} \cdot \mathrm{kg}^{-1}$ protein level and $784 \mathrm{~g} \mathrm{~kg}^{-1}$ for $380 \mathrm{~g} \mathrm{~kg}$ protein level, respectively) compared with those of the control. This is consistent with the results by Forster et al. (2003) and Hernandez et al. (2008), who used MBM as single protein replacement for FM.

In the present study, the crude protein level of the diet was 400 g.kg-1 to 460 g.kg-1, it was higher compared to the some previous studies. In the previous studies showed that the appropriate protein level in practical diets for white shrimp is between 300 and $350 \mathrm{~g} \mathrm{~kg}^{-1}$ (Cuzon et al. 2004). However, the resulting value was renewed to exceed the upper limit range indicated in some current research reports (Goytortu' a-Bores et al. 2006; Venero et al. 2007; Suarez et al. 2009), and this shrimp needs higher CP level in high-salinity water (Zhu et al. 2009). This suggests that white shrimp requires higher-dietary protein level than is usually considered before either in laboratory rearing system or in ponds. This was confirmed by our present result that white shrimps fed a $380 \mathrm{~g}$ $\mathrm{kg}$ )1 CP diet could grow faster than those fed a $330 \mathrm{~g} \mathrm{~kg}$ )1 CP diet at any FM replacement level. The results were further supported by Smith et al. (1985), who pointed that optimal growth for white shrimp was significantly influenced by dietary protein level.

The results of this study indicate that oil could be utilized as a lipid source and can replace up to $50 \%$ of fish oil in diets of $P$. ornatus. Further work to evaluate the efficacy fish head meal as alternative oil sources for fish oil in diets for growing the other lobster species in sea cage conditions also should be addressed.

\section{ACKNOWLEDGMENT}

I would like to give many thanks for Directorate General of Higher Education of Indonesia which has given funding for this research. Also, I would like to give great thanks for Tokyo University of Marine Science and Technology which has given us good facilities to analyze our samples.

\section{REFERENCES}

[1]. Amaya, E., Davis, A. \& Rouse, D. (2007b) Replacement of fish meal in practical diets for the Pacific white shrimp (Litopenaeus vannamei) reared under pond conditions. Aquaculture, 262, 393-401.

[2]. AOAC (1995) Official Methods of Analysis, 16th edn. Association of Official Analytical Chemists (AOAC), Arlington, VA, USA.

[3]. Boyd, C.E. (1979) Water quality in Warmwater Fish Ponds. Auburn University Agricultural Experiment Station, Auburn, AL, USA.

[4]. Cho, C.Y., Cowey, C.B., Watanabe, T., 1985. Finfish Nutrition in Asia: Methodological Approaches to Research and Development. IDRC, Ottawa, Ontario.

[5]. Cruz-Suárez, L.E., Ricque-Marie, D., Tapia-Salazar, M., McCallum,I.M., Hickling, D., 2001. Assessment of differently processed feed pea (Pisum sativum) meals and canola meal (Brassica sp.) in diets for blue shrimp (Litopenaeus stylirostris). Aquaculture 196 (1-2), 87-104.

[6]. Davis, D.A., Arnold, C.R., 2000. Replacement of fish meal in practical diets for the Pacific white shrimp, Litopenaeus vannamei. Aquaculture 185, 291-298.

[7]. Forster, I., 1999. A note on the method of calculating digestibility coefficients of nutrients provided by single ingredients to feeds of aquatic animals. Aquaculture Nutrition 5, 143-145.

[8]. Goytortu' a-Bores, E., Civera-Cerecedo, R., Rocha-Meza, S. and Green-Yee, A. (2006) Partial replacement of red crab (Pleuroncodes planipes) meal for fish meal in practical diets for the white shrimp Litopenaeus vannamei. Effects on growth and in vivo digestibility. Aquaculture, 256, 414-422

[9]. Guo, J., Wang, Y. \& Bureau, D.P. (2007) Inclusion of rendered animal ingredients as fishmeal substitutes in practical diets for cuneate drum, Nibea miichthioides (Chu, Lo et Wu). Aquac. Nutr., 13, 81-87.

[10]. Harter, T., Buhrke, F., Focken, U., Makkar, H.P.S. 2011. Substitution of Fish Meal by Jatropha Curcas Kernel Meal: Effects on Growth Performance and Body Composition of White Leg Shrimp (Litopenaeus vannamei). Aquaculture Nutrition, 17 : $542-548$.

[11]. Hernandez, C., Sarmiento-Pardo, J., Gonzalez-Rodriguez, B. \&Abdode la Parra, I. (2004) Replacement of fish meal with coextruded wet tuna viscera and corn meal in diets for white shrimp (Litopenaeus vannamei, Boone). Aquacult. Res., 36, 834-840. 
[12]. Muzinic, L.A., Thompson, K.R., Morris, A., Webster, C.D., Rouse, D.B. \& Manomaitis, L. (2004) Partial and total replacement of fish meal with soybean meal and brewer's grains with yeast in practical diets for Australian red claw crayfish Cherax quadricarinatus. Aquaculture, 230, 359-376.

[13]. Samocha, T.M., Davis, D.A., Saoud, I.P., DeBault, K., 2004. Substitution of fish meal by co-extruded soybean poultry byproduct meal in practical diets for the Pacific white shrimp, Litopenaeus vannamei. Aquaculture 231, 197-203.

[14]. Smith, L.L., Lee, P.G., Lawrence, A.L. \& Strawn, K. (1985) Growth and digestibility by three sizes of Penaeus vannamei Boone: effects of dietary protein level and protein source. Aquaculture, 46, 85-96.

[15]. Suarez, J.A., Gaxiola, G., Mendoza, R., Cadavid, S., Garcia, G.,Alanis, G., Suarez, A., Faillace, J. \& Cuzon, G. (2009) Substitution of fish meal with plant protein sources and energy budget for white shrimp Litopenaeus vannamei (Boone, 1931). Aquaculture, 289, $118-123$.

[16]. Sudaryono, A., Hoxey, M.J., Kailis, S.G., Evans, L.H., 1995. Investigation of alternative protein sources in practical diets for juvenile shrimp Penaeus monodon. Aquaculture 134, 313-323p

[17]. Tacon, A.G.J., 1987. The Nutrition and Feeding of Farmed Fish and Shrimp-A Training Manual 1. The Essential Nutrients. FAO of the United Nations, Brazil.

[18]. Thompson, K.R., Muzinic, L.A., Engler, L.S. \& Webster, C.D. (2005) Evaluation of practical diets containing different protein levels, with or without fish meal, for juvenile Australian red claw crayfish (Cherax quadricarinatus). Aquaculture, $244,241-249$.

[19]. Zar, J.H. (1984) Biostatistical Analysis. Prentice-Hill, Englewood Cliff, NJ.

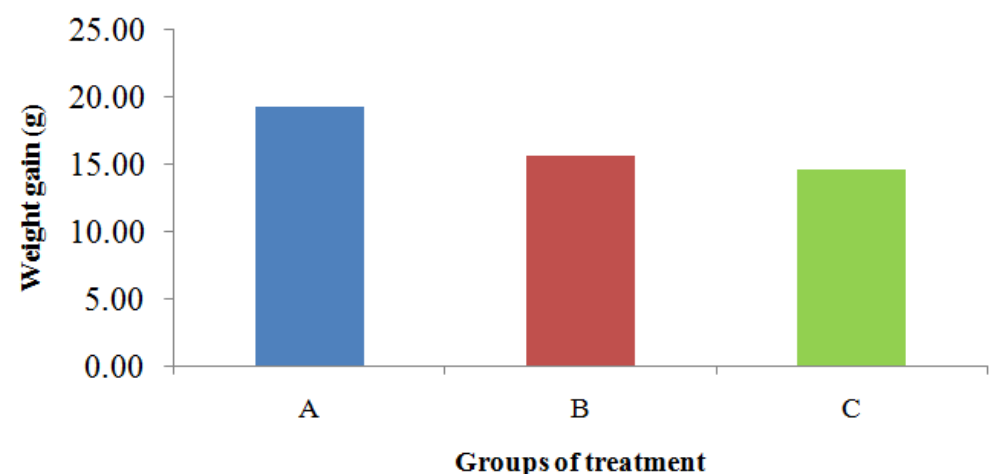

Figure 1. Results of weight gain of lobster

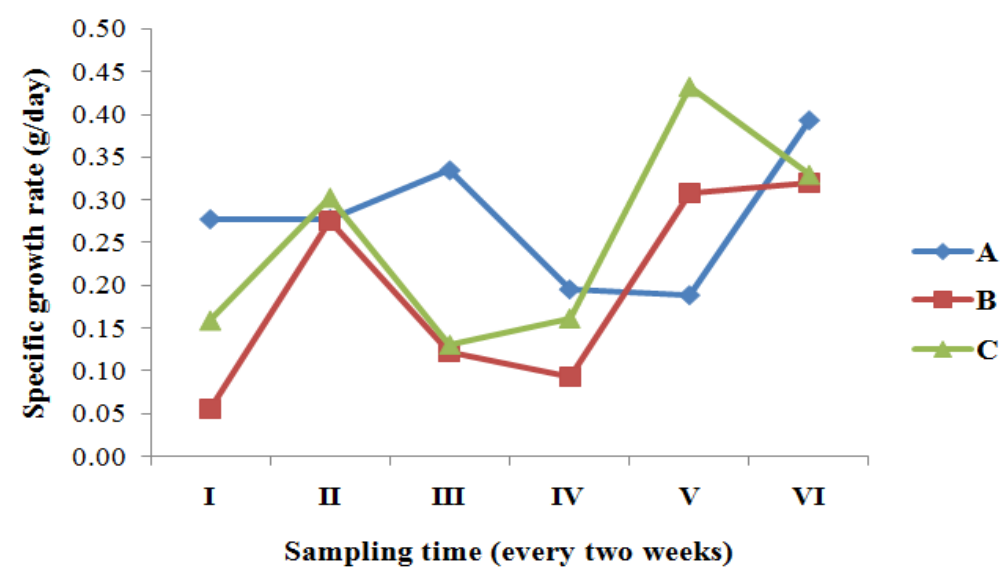

Figure 2. Results of specific growth rate of lobster

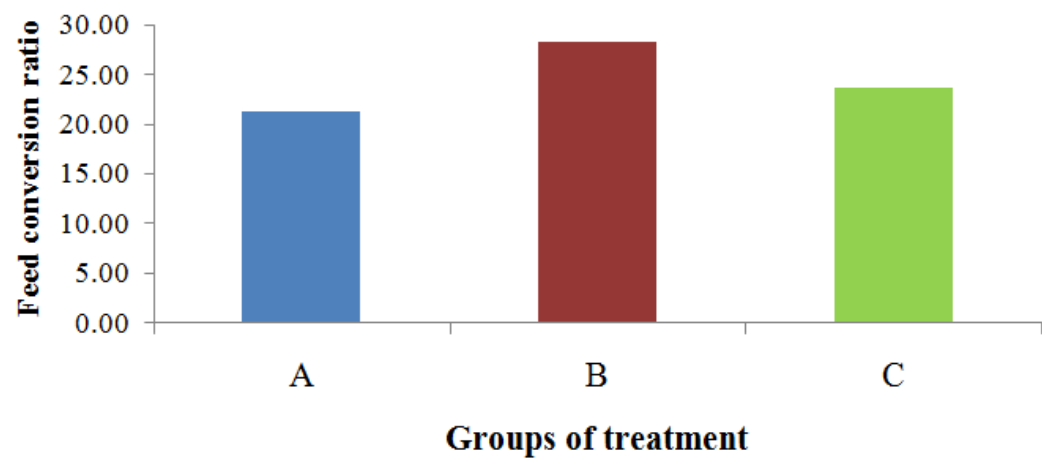

Figure 3. Results of feed conversion ratio of lobster 